\title{
Deepening the Curriculum Construction and Practicing the "Big Class" of Primary School Art
}

\author{
Weibing Qiu \\ School of Art and Design \\ Xihua University \\ Chengdu, China 610039
}

\begin{abstract}
In recent years, China has invested more and more heavily in basic education, not only in the construction of traditional cultural courses, but also in the construction of art classes in primary schools. It has extended the original art and music courses and introducing related art types such as film, television, dance, drama and so on. To deepen curriculum construction, art teaching should be an important part of primary school teaching. The primary school art class adopts various forms of art courses to achieve cross-integration and mutual penetration of various disciplines, so that social life and art are closely linked to enhance the artistic level of primary school students.
\end{abstract}

Keywords-curriculum construction; primary school art class; deepening curriculum

\section{INTRODUCTION}

Chinese investment in basic education has become more and more powerful. In the original primary school curriculum, there are only two art courses, art and music. With the reform of education, film and television, dance, and drama have gradually entered the primary school art class. Art education is a new type of education concept. In the process of teaching, primary school teachers need to conduct in-depth research continuously to achieve comprehensive infiltration of various disciplines so that primary school students can enjoy art education in a good environment. Deepening the curriculum reform and realizing the big classroom of primary school art will help the development of art education in primary education.

\section{THE SIGNIFICANCE OF ART CURRICULUM CONSTRUCTION IN PRIMARY EDUCATION}

Under the premise of original music and art, the primary school art class combines various artistic expressions such as calligraphy, dance, and drama, and uses creative means to reflect various artistic problems that appear in the cultural science society. Art innovation teaching practice activities can enhance students' cultural quality and life emotions. The art class in primary schools does not superimpose the number of various art disciplines, but helps students improve their art expression ability, art innovation ability, crossregional transformation ability and art appreciation ability while studying various art disciplines.
The goal of curriculum construction in the classroom is mainly reflected in the following: First, innovating the foundation of art theory and realizing the integration of primary school art classes. Second, students can learn through simple art types and be able to appreciate, perceive, create, express, evaluate, reflect, cooperate, and communicate. Students should respect life, care for nature, be friendly, and learn to share in the art course so that their humanistic qualities can be comprehensively improved. Third, primary school students through the art classroom to improve the ability of comprehensive art innovation and art design. It can not only realize the appreciation of art in class, but also actively organize art practice activities in life. Fourth, primary school students have the initial appreciation of art, organizational and coordination skills, and innovative ability in the art class learning in primary schools, which can lay a good foundation for the subsequent art courses.

\section{StRATEGIES FOR DEEPENING CURRICULUM CONSTRUCTION AND DEVELOPING ART Classes}

\section{A. Implementing the National Art Curriculum Policy}

In order to actively carry out the design of the art classroom, the school should strictly upgrade the art curriculum at the primary level to about $9 \%$ of the total curriculum in accordance with the relevant requirements of the national curriculum plan, so as to ensure that the art curriculum is implemented in time. At the same time, the school should actively implement the primary school art curriculum. On the basis of the original art and music courses, it will introduce a variety of art curriculum forms, set up rookie competitions, exchange books and share topics, and ensure the significance of art courses. The school should conscientiously understand the spirit of the national art curriculum, and formulate a reasonable primary school art curriculum according to the characteristics of the school itself, so that the art curriculum can reach all aspects of the life of primary school students.

\section{B. Creating a Teaching Atmosphere for Art Courses}

In the process of primary school art cultivation, attention is paid to emotional experience, highlighting the characteristics of art courses. When primary school students study art courses, they can cultivate noble moral qualities, love the good qualities of life, and good humanistic qualities. 
In the process of building the art class curriculum, the school should pay attention to creating a good atmosphere of art curriculum and embody the culture of educating people. In the process of learning art, students can purify the minds and enhance the quality of their beauty. Art class is a kind of popular education. In the teaching of art course, teachers should focus on the less difficult and effective works, emphasizing the ability of students to participate in art classes, so that students can improve their interest in learning art. The values and attitudes of primary school students vary from individual to individual. Although these emotions have a direct relationship with intelligence, primary school students 'emotional attitudes and values more often affect their behavior and judgment in a non-intellectual manner. At the end of each semester, the school allows students to extend and expand their study on the content they are interested in. For example, after learning the paper-cutting art course in the lower grade, teachers can integrate the national art culture and tell students about the history of paper-cutting culture, so that students can better learn papercutting art. For example, after enjoying the folk music, middle-aged students may have a strong interest in the wonderful performance of the teacher. They have a strong desire for knowledge of the national musical instruments. After class, children will find relevant music to appreciate, which is helpful to the inheritance of national music.

\section{Conducting Curriculum-based Artistic Activities}

In order to improve the enthusiasm of students to learn art, many schools carry out campus art festivals to promote the in-depth reform of art curriculum education. Art festivals in schools are generally conducted in the way of "Competition first, Performance later". This management model emphasizes the display of results and has a certain degree of contempt for the educational process. Therefore, schools should actively explore new methods for the curriculum of artistic activities. In order to fully utilize the charm of art, many schools have developed relevant teaching courses for instrumental music, dance, singing, public welfare, painting, and calligraphy, and encourage students to display teaching results in class. The school will also formulate relevant examinations or competitions to enable the festival to effectively connect with the classroom learning, and truly realize the curriculum and normalization of artistic activities.

\section{Integration of Artistic Social Resources}

The development of art courses in primary schools is not enough for the school. Therefore, it is necessary to actively integrate the resources of the society so that primary school students can enjoy the environment of art learning both inside and outside the school and improve the quality of art learning. For example, some professional youth activity centers are unique in the art teaching model. They have more complete art teaching facilities and professional teaching staff, and they can systematically and comprehensively provide primary school students with professional art practice forms. The schools can actively cooperate with these professional youth activity centers in art teaching. Every afternoon, they can take turns to transport students to learn various art forms, such as hard-pen calligraphy, creative sketch, children's color, vocal music, instrumental music, hip-hop dance, ballet, national dance, Latin dance, etc. The active cooperation between the school and the activity center helps to integrate social resources and provide a good artistic learning environment for primary school students, thus improving the quality of art teaching. In the process of conducting art courses, the school can combine local regional cultural characteristics, formulate reasonable teaching plans, maximize the integration of social resources, and deepen curriculum construction.

\section{E. Construction of Standardized Art Societies}

With the development of the primary school art class, many schools have established a variety of art societies, such as painting clubs, music clubs, dance clubs, photography clubs, animation clubs, etc., which have a positive effect on students' learning of art. The degree of standardization of art associations is related to the construction of art activities in schools. Schools should adopt standardized management mode and establish and improve the operation system of art associations. Associations must have evaluation systems, management systems, professional teachers and teaching plans. The various teaching activities of the association can be closely linked with various activities of the school, leading students into the atmosphere of art. For example, in the operation mode of primary school photography community, professional photography association expert team can be invited to come to school regularly to explain photography knowledge and guide students to shoot relevant film and television materials. And invite some celebrities who like photography to give professional speeches in the school to arouse students' interest in the art of photography.

\section{F. Conducting a Hierarchical Art Curriculum}

In the teaching of elementary school art, pupils at different stages must have different methods of art teaching. Teachers should develop an art syllabus that meets the psychological characteristics and learning needs of students, including teaching resources, teaching steps, teaching objectives, and teaching themes, so that students can enhance their perception and artistic appreciation in art learning. In the process of art course construction, it is necessary to integrate poetry, fairy tales, games and other teaching modes to encourage students to actively participate in the practice of art activities. When students in the lower grades study art, they mainly cultivate their interest in art, enhance their performance ability, and expand their artistic vision. Students in the Middle grade of primary school must be one step higher than those in the lower grade. They must have a strong ability to perceive a variety of art forms. For example, the point-to-face teaching mode, in the process of learning fine arts, it is possible to integrate a variety of art forms. In the upper grades of primary school, students are required to closely unite art history and traditional culture to enhance their understanding of art and create a good artistic learning environment. The school should deepen the curriculum construction, actively create a good artistic atmosphere for the students, let them experience the noble realm of art, and develop a sound psychology and complete personality in the 
process of artistic literacy improvement. For example, in the process of learning art, there are several aspects to be aware of: First, the art is closely related to other art disciplines, so as to carry out point-to-face teaching mode. Secondly, teachers should change the traditional boring teaching mode, and adopt the subject-based learning, which is dominated by students, to ensure that students can master the knowledge and skills of art painting from shallow to deep. At the same time, schools should also take into account the combination of art courses and school-running characteristics, so that art teaching has timeliness and operability.

\section{G. Actively Encouraging Cooperation and Art Teaching Exploration}

In the process of primary school art classroom teaching, cooperation and inquiry teaching has always been the teaching mode advocated by curriculum reform. Through the communication of the group, the primary school students can learn a broader cultural background and communicate well with adults, peers and the surrounding environment to improve their own quality. Cooperative inquiry learning is conducive to the strengthening of skills and knowledge, and it is more conducive to the social development of students. It also has important significance for cultivating good quality and cooperation spirit. In the art curriculum teaching activities, cooperation and inquiry are usually a wonderful experience for students. Rich imagination and creativity can give more tension and vitality to teaching. In the process of self-learning and inquiry, students will consciously discover beauty, experience beauty and express beauty. In the cooperative and inquiry teaching mode, experiential teaching mainly emphasizes the integration of the knowledge about art learned in the process of experiencing from the individual students. Primary school art teaching activities are not only knowledge teaching, but also emphasize inner perception and experience ability of students. Therefore, teachers should change the teaching mode of art, let students actively participate in group cooperation and exploration, express their views, and improve the efficiency of art learning.

\section{The Evaluation OF PRIMARY SCHOOL ART CURRICULUM CONSTRUCTION}

\section{A. Diversification of Art Curriculum Evaluation Indicators}

Primary school art teaching emphasizes students' perceptual cognition. Therefore, schools should establish an objective and comprehensive evaluation system, which not only examines the application of students' professional knowledge, but also objectively evaluates students' artistic performance. For example, in the art teaching process, the teacher's art curriculum evaluation indicators are: awards, participation in the second classroom, painting skills, creativity, appreciation, learning attitudes and habits. Based on these first-level indicators, teachers refine many indicators of the second or third level to form a corresponding evaluation index system. In the past art teaching process, three forms of painting demonstration, creative design and appreciation were adopted. Nowadays, the art class pays more attention to the students' feelings. The students are not only hand-painted, but can express their feelings about the related works, and can also make impromptu creative adaptations. Students' performance can help them exercise their courage, know themselves and experience success.

\section{B. Adopting a Diverse Art Subject Evaluation}

In the course of the construction of primary school art classroom, teachers always evaluate the teaching and neglect the main position of students. With the development of diversified teaching, students, students and parents can participate in the curriculum evaluation, which can fully reflect the diversity of art courses. A comprehensive evaluation of the students' artistic learning ability can avoid the one-sidedness, concentration and subjectivity of the evaluation, thus make more scientific comments on students. Mutual evaluation among students helps students to recognize the shortcomings in the process of art learning and treat problems objectively. And the comments from parents help students to appreciate the charm of art in a good learning atmosphere.

\section{Evaluation Timing Is Oriented to the Entire Process}

In the course of the construction of art curriculum in primary schools, it is necessary to pay attention to the timing of evaluation. The evaluation of students' learning is to enable students to better study art. Therefore, the teacher should supervise the student's artistic learning effect throughout the whole process, conduct a full evaluation, and adopt daily evaluation, stage evaluation, and semester general evaluation. The daily evaluation mainly focuses on the students' differential comments. After each class study, they comment on the students' basic abilities, basic knowledge learning, and attitudes, and make corresponding records. Stage evaluation generally refers to the comprehensive evaluation of students after a stage of learning, focusing on the good results achieved by students in this stage. The final general assessment is mainly a comprehensive evaluation of the effect of students' art learning in this semester, so that students can clearly understand what art knowledge they have mastered in the course of this semester, which will help them to improve their literacy. There will be some differences in the evaluation of students at different stages. Therefore, teachers should establish a dynamic management model, pay attention to the learning effect of students at each stage, continuously improve the artistic quality of students, and master a more comprehensive artistic knowledge.

\section{CONCLUSION}

In the process of primary school art classroom teaching, teachers should deepen the curriculum construction, formulate reasonable teaching strategies according to the actual situation of students, and encourage primary school students to actively study art. Conducting good art studies can enhance the overall quality of students and their personal cultural accomplishments. Teachers should develop a good curriculum teaching strategy, and objectively and impartially evaluate students' learning effects, improve students' interest 
in learning art, and promote the comprehensive development of primary school art classroom curriculum construction.

\section{REFERENCES}

[1] Zhang Xi, Jiang Nu, Yang Xiaofeng. Practical Research on Schoolbased Development of Primary School Art Courses [J]. Chinese Teachers, 2014 (12): 51-52. (in Chinese)

[2] Liang Huiquan. Deepening the Curriculum Construction and Constructing a Large Classroom for Primary School Art Education [J]. Guangdong Education (Comprehensive Edition), 2012 (12): 45-46. (in Chinese)

[3] Gao Xiaoliang. Practice and Thinking of the Construction of Chinese Photography Art Course[J]. New Curriculum Elementary School, 2012, (3): 52-53. (in Chinese)

[4] Huang Qiong. Thoughts and Countermeasures in the Training of Music Teachers [J]. Art 100, 2012, (6): 85-86. (in Chinese)

[5] Ni Jing. Art Courses for Students to Insert Invisible Wings [J] Beijing Education, 2013, (7): 16-18. (in Chinese)

[6] Shen Huifen. On the Education of Children's Experiential Art Course[J]. Primay Science, 2013, (2): 52-53. (in Chinese)

[7] Wu Yanru. Research on the Construction of Music Curriculum for Primary Education in China[J]. Curriculum and Teaching Theory, 2013, (7): 85-86. (in Chinese)

[8] Kong Deming. Evaluation of Art Classroom Teaching in Primary and Secondary Schools [J]. Happy Reading, 2011, (1): 16-18. (in Chinese) 